\title{
Pendidikan Multikultural dalam Keluarga Waria: Perjuangan dan Hak-Hak Minoritas Kaum Waria di Tanjungpinang
}

Oleh:

\author{
Marisa Elsera dan Sri Wahyuni ${ }^{1}$
}

\begin{abstract}
Abstrak
Pendidikan berarti proses pengembangan sikap dan tata laku seseorang atau kelompok dalam usaha mendewasakan melalui pengajaran, pelatihan, proses dan cara mendidik. Sementara multikultural diartikan sebagai keragaman kebudayaan, keanekaragaman nilai dan norma yang dianut masyarakat. Mengetengahkan konsep pendidikan multikultural berarti mengimplementasikan gagasan tentang keragaman kebudayaan dan aneka kesponan tersebut. Namun sebelum mempelajari multikultural, tentu harus dipahami tentang kultur, yakni sebuah budaya yang bersifat universal bagi manusia. Sehingga jelaslah bahwa masyarakat multikultural adalah masyarakat yang menganut sekumpulan simbol yang mengikat di dalam sebuah masyarakat untuk diterapkan seperti penjelasan Emile Durkheim dan Marcel Maus.

Pendidikan multikultural perlu ditanamkan sejak dini, melalui sosialisasi primer dan sekunder seperti di sekolah. Misalnya dengan mempelajari simbol-simbol dan identitas yang beragam sebagai ciri masyarakat multikultural. Hal ini menjadi penting guna menghindari konflik sosial yang dewasa ini sering kali terjadi dalam bentuk kekerasan, konflik antaretnik hingga "legitimasi keagamaan" yang diajarkan dalam pendidikan agama di daerah yang rawan konflik tak terkecuali di daerah perbatasan. Konflik yang mengakar dan dikemas sebagai sebuah "keyakinan keagamaan" membuat konflik sosial yang biasanya berbentuk kekerasan dan anarkisme (termasuk bully dan kabar hoax) semakin sulit diatasi.

Pendidikan multikultural menjadi sangat menarik ketika diteliti pada keluarga waria di Tanjungpinang. Penelitian ini berhasil menemukan bagaimana nilai dan norma yang beranekaragam dalam kebudayaan Indonesia ditanamkan dalam keluarga waria di Tanjungpinang sejak kecil. Tidak hanya pengajaran tentang menghargai keragaman budaya, tapi juga diajarkan tentang sosialisasi nilai kebhinekaan dalam keluarga. Sehingga realitas obyektif tentang pendidikan multicultural dapat terinternalisasi dengan cukup baik pada waria di Tanjungpinang, terbukti dengan kegiatan-kegiatan rutin bulanan dan insedentil yang dilakukan oleh waria.
\end{abstract}

\section{Keyword: Pendidikan, Kultur, Multikultural dan Etnik}

\footnotetext{
${ }^{1}$ Staff Pengajar atau Dosen Sosiologi UMRAH, Tanjungpinang. Email (marisaelsera@yahoo.com)
} 


\section{PENDAHULUAN}

Ide tentang masyarakat multikultural adalah kebijakan publik resmi. Premis dasar dari multikulturalisme adalah tentang bagaimana menunjukkan toleransi terhadap keanekaragaman praktik budaya dalam konteks negara. Pendidikan multikultural bertujuan untuk mengekspresikan rasa hormat terhadap perayaan atas perbedaan. Oleh sebab itu, menjadi penting untuk melaksanakan pendidikan multicultural di Indonesia mengingat masyarakat Indonesia adalah masyarakat yang multikultur.

Secara etimologi istilah pendidikan multikultural terdiri dari dua term, yaitu pendidikan dan multikultural. Pendidikan berarti proses pengembangan sikap dan tata laku seseorang atau kelompok dalam usaha mendewasakan melalui pengajaran, pelatihan, proses dan cara mendidik,dan multikultural diartikan sebagai keragaman kebudayaan, aneka kesopanan. Akar kata dalam memahami multikultural adalah kultur.

E. B. taylor, L. H. Morgan, yang mengartikan kultur sebagai sebuah budaya yang universal bagi manusia dalam berbagai macam tingkatan yang dianut oleh seluruh anggota masyarakat. Emile Durkheim dan Marcel Maus menjelaskan bahwa kultur adalah sekelompok masyarakat yang menganut sekumpulan simbol-simbol yang mengikat di dalam sebuah masyarakat untuk diterapkan. Margareth Mead menjelaskan bahwa kultur adalah kepribadian yang ditulius dengan laus, bentuk-bentuk dan sekaligus terbentuknya kepribadian tersebut ditentukan oleh kepribadian para anggotanya.

Para pengkritik multikuturalisme dari dalam ranah kajian budaya menyoroti pentingnya kinerja kekuasaan dan mereka juga menantang praktik ideologis dan struktural yang membentuk sebagian wajah masyarakat yang rasis. Dengan mengetengahkan pendidikan multicultural dinilai mereka justru akan menyamaratakan (homogenizing) pengalaman budaya dari pada mengakui kemajemukan serta hibriditas yang memang sudah tertanam dalam identitas kultural kontemporer.

Masyarakat multikultural pada umumnya adalah masyarakat yang terbuka dan punya toleransi tinggi terhadap perbedaan. Ruang keterbukaan terhadap perbedaan inilah yang akhirnya membuat kelompok minoritas dapat berkembang. Seperti halnya Kota Tanjungpinang yang merupakan kota multietnis membuka toleransi terhadap perbedaan etnis yang ada. Tanjungpinang merupakan ibukota Provinsi Kepuluan Riau yang terdiri dari multietnis. Sebagai wilayah yang dihuni oleh mayoritas perantau, Tanjungpinang menjadi wilayah yang strategis 
untuk dijadikan lokus penelitian tentang pendidikan multikultural yang ada di Kepulauan Riau. Berikut komposisi etnis Kota Tanjungpinang:

\section{Tabel 1}

\section{Komposisi Etnis Kota Tanjungpinang}

\begin{tabular}{|l|c|}
\hline Etnis & Jumlah (\%) \\
\hline Melayu & 30,7 \\
\hline Jawa & 27,9 \\
\hline Tionghoa & 13,5 \\
\hline Minangkabau & 9,5 \\
\hline Batak & 6,6 \\
\hline Sunda & 2,8 \\
\hline Bugis & 1,9 \\
\hline Lain-lain & 7,1 \\
\hline
\end{tabular}

Sumber: Sensus Penduduk Tahun 2010 ${ }^{[5]}$

Suku Melayu merupakan penduduk asli dan kelompok suku bangsa terbesar di Tanjungpinang. Disamping itu terdapat pula Suku Bugis, Suku Minang, Orang Laut dan Tionghoa yang sudah ratusan tahun berbaur dengan Suku Melayu dan menjadi penduduk tetap semenjak zaman Kesultanan Johor-Riau dan ResidentieRiouw. SukuBugis awalnya menetap di Kampung Bugis dan Suku
Tionghoa banyak menempati Jalan Merdeka dan Pagar Batu. Setelah masa kemerdekaan, orang Jawa dan Minang mulai ramai mendatangi Tanjungpinang. Dimana orang Minang sebagian besar menempati pemukiman di sekitar pasar ${ }^{[6]}$, sedangkan Suku Jawa banyak yang bermukim di Kampung Jawa. Bahasa yang digunakan di Tanjungpinang adalah Bahasa Melayu klasik. Bahasa Melayu di kota ini hampir sama dengan Bahasa Melayu yang digunakan di Singapura. Disamping itu, banyak pula yang menggunakan Bahasa

Jawa, Minangkabau dan Batak. Masyarakat Tionghoa di Tanjungpinang pun masihmenggunakan BahasaTiochiu dan Hokki enam dalam berkomunikasi. Kendati masyarakat Tanjungpinang merupakan masyarakat multikultural, namun ternyata ada keberadaan subkultur belum dapat diterima secara menyeluruh, khususnya subkultur yang dianggap menyimpang. Subkultur menyimpang adalah sekumpulan norma, nilai dan kepercayaan berbeda dan cenderung menyimpang dari nilai-nilai yang dianut oleh kultur masyarakat yang paling dominan namun masih menjadi bagian dari kultur dominan dan para anggotanya masih terlibat atau berpartisipasi di dalam kehidupan masyarakat dari kultur dominannya. 
Salah satu subkultur menyimpang yang ada di Tanjungpinang yakni kelompok waria yang tergabung dalam Forum Komunikasi Rumpun Waria Sehati (FKRWS) Tanjungpinang. Sekelompok waria yang merasakan ansib yang sama kemudian menjalin hubungan karena kepentingan yang sama yakni untuk menghindari punishment yang akan diberikan jika teridentifikasi sebagai pelaku penyimpangan. Tulisan ini mengkaji bagaimana perjuangan waria di Tanah Melayu Tanjungpinang sebagai kelompok minoritas dan mengidentifikasi bagaimana pendidikan multikultural yang terinternalisasi pada para waria dan masyarakat Tanjungpinang.

\section{PEMBAHASAN}

Waria atau transsexual yaitu keinginan untuk hidup dan diterima sebagai anggota kelompok lawan jenis, biasanya disertai dengan rasa tidak nyaman atau tidak sesuai dengan jenis kelamin anatomisnya dan menginginkan untuk membedah jenis kelamin serta menjalani terapi hormonal agar tubuhnya sepadan dengan jenis kelamin yang diinginkan.

Sebagai kelompok rentan, sebenarnya keberadaan waria sudah dijamin dalam UU No 39/1999 tentang Hak Azasi Manusia. Pasal 3 ayat (3) UU tersebut berbunyi ,'Setiap orang berhak atas perlindungan hak asasi manusia dan kebebasan dasar manusia, tanpa diskriminasi" dan Pasal 5 ayat 3 menyatakan, “ Setiap orang yang termasuk kelompok masyarakat yang rentan berhak memperoleh perlakuan dan perlindungan lebih berkenaan dengan kekhususannya." Namun sekalipun UU N0 39/1999 menjadi dasar hukum yang kuat bagi waria untuk memperoleh perlakuan yang adil dari negara, kenyataan di lapangan selama ini waria belum diperlakukan sebagaimana warga negara ,normale lainnya. Aksesibilitas terhadap pelayanan publik dasar belum diberikan oleh pemerintah Indonesia.

Kemunculan waria (wanita-pria) sudah menggejala di Tanjungpinang. Kendati Kota Tanjungpinang identik dengan Tanah Melayu dimana menganut filosofi adat bersandikan syarak dan syarak bersandikan kitabullah, namun keberadaan waria tidak dapat ditepis. Beberapa titik di Kota Tanjungpinang digunakan sebagai tempat berkumpulnya kaum waria hampir setiap malam seperti Lapangan Pamedan, Tenis Ban dan Monumen Raja Haji Fisabilillah.

Kendati keberadaan waria di Tanjungpinang dikategorikan dalam kelompok minoritas. Artinya, secara kuantiatif waria masih sedikit dibandingkan masyarakat “normal".Seperti halnya kaum minoritas lainnya, waria juga mengalami diskriminasi, eksploitasi, ketidak adilan serta ketidak setaraan. Padahal, setiap individu dijamin 
kebebasannya untuk melanjutkan hidup yang berbeda tanpa ada interfensi. Setiap individu bebas membentuk atau bergabung dalam berbagai perkumpulan dan mencari anggota baru bagi perkumpulan itu dalam "ajang kebudayaan". Atas pandangan itu, memberikan pengakuan politik atau dukungan pada perhimpunan budaya tertentu adalah tidak perlu karena suatu cara hidup yang berharga tidak mempunyai kesulitan dalam menarik pengikut.

Meskipun Kota Tanjungpinang adalah kota yang multietnis dan masyarakatnya terbilang mampu bertoleransi antaretnis, namun ruang toleransi itu ternyata belum bisa terbuka sepenuhnya bagi subkultur menyimpang seperti waria. Nyatanya keberadaan waria di Tanjungpinang masih mengalami diskriminasi dan ketidaksetaraan. Oleh sebab itu, tak mengherankan ketika waria di Tanjungpinang berupaya untuk dapat diterima dan terintegrasi dengan masyarakat mayoritas.

Pemerintah kota Tanjungpinang dan masyarakat pada umumnya mengidentifikasi waria sebagai jenis kelaminnya ketimbang gendernya. Hal ini pada akhirnya berimplikasi pada terjadinya diskriminasi terhadap waria untuk memperoleh pelayanan publik dasar sebagaimana dialami waria di Kota
Tanjungpinang. Para informan pernah mengaku mengalami kesulitan diterima sebagai siswa di lembaga pendidikan formal, bekerja sebagai karyawan swasta (sampai dipecat) begitupun dengan PNS.

Para informan pun mengaku sering dilecehkan secara verbal saat ingin memanfaatkan sarana dan prasarana public. Informan mengalami tindak kekerasan dan pelecehan seksual secara verbal dan fisik khususnya waria yang berprofesi sebagai pelacur jalanan, mereka pernah dilempari sampah hingga air keras ketika berdiri di jalan. Berangkat dari pengalaman buruk itu, maka waria di Tanjungpinang berupaya melakukan aktivitas sosial yang bertujuan untuk mempertunjukkan eksistensi dan kepedulian mereka pada isu sosial yang berkembang di masyarakat.

Tuntutan agar diterimanya subkultur menyimpang pada masyarakat Tanjungpinang menjadi tantangan tersendiri. Perjuangan waria sebagai kelompok minoritas untuk mendapatkan pengakuan atas identitas mereka dari kelompok mayoritas membutuhkan usaha yang lebih besar. Pihak mayoritas menuduhkan bahwa akan terjadi gap atau pengkotakkan yang dapat mengganggu integrasi mayoritas dan minoritas. Tuduhan itu agak berlebihan apalagi jika terjadi pengabaian atas motivasi 
kelompok minoritas. Tuduhan yang seperti itu juga dialami oleh waria sebagai kelompok minoritas di Kota Tanjungpinang.

Kelompok waria yang ada di Tanjungpinang memiliki keinginan untuk berintegrasi ke dalam masyarakat yang lebih besar dan dapat diterima sebagai anggota penuh masyarakat tersebut. Mereka kemudian mencari pengakuan yang lebih besar atas identitas kelompok mereka, bukan untuk menjadi terpisah melainkan untuk mendapatkan penerimaan atas perbedaan mereka. Oleh sebab itulah mereka membentuk kelompok minoritas untuk mempertegas identitas dan aspirasi mereka yang diwujudkan dalam Forum Komunikasi Rumpun Waria Sehati (FKRWS). Berikut data waria anggota FKRWS yang ada di Tanjungpinang:

\section{Tabel 1}

Data Waria di Kota Tanjungpinang Berdasarkan Usia

\begin{tabular}{|l|l|l|}
\hline No & Usia Waria & Jumlah \\
\hline 1 & $16-25$ tahun & 15 orang \\
\hline 2 & $26-35$ tahun & 19 orang \\
\hline 3 & $36-45$ tahun & 7 orang \\
\hline 4 & 46 tahun> & 4 orang \\
\hline & Total & 45 orang \\
\hline
\end{tabular}

Sumber: FKRWS 2017

Berdasarkan tabel di atas, waria yang ada di Tanjungpinang adalah waria yang berusia produktif, yakni lebih dari $75 \%$. Berikut ini data waria berdasarkan pekerjaan tetapnya:

Tabel 2

Data Waria di Kota Tanjungpinang

Berdasarkan Pekerjaan Tetap

\begin{tabular}{|l|l|l|}
\hline No & Pekerjaan Waria & Jumlah \\
\hline 1 & Salon & 26 orang \\
\hline 2 & LSM HIV/AIDS & 8 orang \\
\hline 3 & PNS & 1 orang \\
\hline 4 & Swasta & 10 orang \\
\hline & Total & 45 orang \\
\hline
\end{tabular}

Sumber: FKRWS 2017

Sebagian besar waria di Kota Tanjungpinang bekerja sebagai hair styles dan make up artis. Bidang pekerjaan ini mendominasi karena salon tidak hanya sebagai tempat bekerja tapi basecamp waria dalam aktifitas sehari-hari. Meski sudah punya pekerjaan tetap, berdasarkan penelitian ini $60 \%$ waria di Kota Tanjungpinang bekerja sebagai pekerja seks. Mereka menjadi pekerja seks dengan cara "mangkal" di Lapangan Pamedan KM 4, sekitar LANTANAL dan Tenis Ban (belakang gedung daerah) pada malam hari yakni pukul 22.00-dini hari.

Keberadaan waria di Tanjungpinang sebenarnya bertentangan dengan kolektivitas masyarakat di Tanjungpinang. Padahal, masyarakat kolektif itu direkatkan dan dihidupi oleh dominannya nilai-nilai kebersamaan, sementara masyarakat individualis lebih 
dihidupi oleh nilai-nilai otonomi pribadi dan kebebasan kreatif individu dimana diri dihargai karena keunikannya sebagai seorang pribadi. Hal terakhir inilah yang terjadi pada waria di Tanjungpinang, dimana mereka dihidupi oleh nilai-nilai otonomi pribadi yang bertentangan dengan nilai kebersamaan yang mempererat masyarakat kolektif. Menyadari hal tersebut, waria di Tanjungpinang berupaya untuk memperkenalkan diri dan mengupayakan agar keberadaan mereka dapat diterima oleh masyarakat Tanjungpinang meskipun terkadang secara performance dan pilihan hidup bertentangan dengan nilai-nilai kebersamaan.

Hal menarik yang teridentifikasi dari waria di Tanjungpinang adalah ada pendidikan multikultural yang mereka dapat dari keluarga yang menjadikan rasa nasionalisme dan kecintaan terhadap tanah air tercermin dalam keseharian waria baik sebagai individu maupun dalam kelompok FKRWS. Keluarga batih memiliki peran penting dalam kehidupan waria terutama dalam menanamkan nilai toleransi antar masyarakat. Pendidikan multikultural yang ditanamkan keluarga informan waria seperti adil dan objektif dalam memandang status sosial ekonomi, gender, orientasi seksual, etnis, ras dan budaya. Keluarga informan waria ini adalah terdiri dari penggiat seni, seperti pemain wayang orang, penari dan penyanyi. Mereka sudah terbiasa dihadapkan pada keberagaman budaya dan seni di Indonesia. Sehingga mereka mampu menerima perbedaan yang ada. Termasuk tentang gender dan orientasi seksual yang mereka pandang sebagai sebuah pilihan hidup yang menjadi hak setiap manusia. Berikut ini penjelasannya:

1. Adil dan objektif dalam memandang status sosial ekonomi, gender, orientasi seksual, etnis, ras dan budaya. Informan dibesarkan dalam lingkungan masyarakat yang tidak mau menerima keberadaan mereka di kampung halaman karena dianggap menyimpang dari norma yang dipegang. Mereka memang secara langsung tidak mengalami pengusiran dari kampung halamannya, namun secara tidak langsung perlakuan masyarakat yang diskriminatif, kerap membully dan memandang mereka sebagai orang-orang yang sakit maka mereka memutuskan untuk merantau. Merasakan tidak enaknya diperlakukan secara diskriminatif tidak membuat informaninforman memperlakukan orang lain secara diskriminatif pula. Mereka memahami sebagai kelompok minoritas maka mereka harus mampu menyesuaikan diri dengan lingkungan 
sekitarnya. Oleh sebab itu, mereka memang mengaku berupaya keras untuk memahami masyarakat karena menyadari bahwa masyarakat tidak mau memahami mereka. Mereka berharap masyarakat pun bisa adil dan objektif dalam memandang status sosial ekonomi, gender, orientasi seksual, etnis, ras dan budaya oleh sebab itu mereka menunjukkan hal tersebut dalam kegiatan sosial dan keseharian mereka.

2. Penggiat seni, seperti pemain wayang orang, penari dan penyanyi. Para waria adalah orang-orang yang sudah terbiasa dihadapkan pada keberagaman budaya dan seni di Indonesia dalam keluarga intinya. Oleh sebab itu, mereka memang dari kecil sudah di ajarkan tentang keberagaman tersebut. Bahwa orangorang terdiferensiasi namun hal itu dapat dimaklumi dan bukan menjadi sumber konflik. Mereka meyakini bahwa ketidaksamaan itu sebenarnya adalah kekayaan budaya Indonesia yang bisa menjadi kekuatan di internasional. Oleh sebab itu, mereka terkadang mengaku tidak dapat memahami jika kehadiran mereka di tanah kelahiran mereka ternyata masih belum bisa diterima, malah kehadiran mereka di tanah melayu yang dirasakan cukup diterima oleh masyarakat sekitarnya. Tanjungpinang dianggap sebagai kota yang cukup mewakili ke-multikultural-an Indonesia. Miniatur Indonesia tampak di Tanjungpinang.

Meski memiliki realitas subyektif yang berbenturan dengan realitas obyektif, nyatanya mereka berupaya untuk tetap berbaur dengan masyarakat pada umumnya. Adapun hal yang dilakukan oleh waria di Tanjungpinang guna mendapatkan penerimaan dalam masyarakat adalah sebagai berikut:

1. Terlibat dalam Kegiatan Sosial.

Para waria di Tanjungpinang yang tergabung dalam FKRWS aktif dalam kegiatan-kegiatan sosial seperti pencegahan HIV/AIDS di Tanjungpinang. Waria FKRWS mendukung kegiatan Support Grant For Operation ISEAN HIVOS Program GWL-INA pada Agustus 2017.Dengan adanya dukungan Dana Operasional dari GWL-INA ini, FK-RWS lebih mampu untuk meningkatkan program penanggulangan HIVdan AIDS terutama di kalangan Waria, meningkatkan pengetahuan tentang SOGIE, mendukung kualitas kesehatan seksual dan reproduksi serta mengurangi stigma dan diskriminasi di komunitas Waria di Kota Tanjungpinang. Waria yang tergabung dalam FKRWS bekerjasama dengan petugas medis 
lapangan dari Dinas Kesehatan Kota

Tanjungpinang melakukan outreach dengan mendatangi Hotspots-hotspot Waria dengan tujuan memberikan informasi kesehatan tentang HIV dan AIDS, IMS dan akses Layanan serta membagi-bagikan kondom dan pelicin ke teman-teman Waria.

Tergabungnya waria ke dalam kegiatan sosial dan kesehatan ini bertujuan untuk merangkul waria lainnya yang belum tergabung dalam komunitas untuk mengakses layanan kesehatan, menjadi agen sosialisasi yang memberikan informasi kesehatan tentang IMS, HIV dan AIDS serta berkoordinasi dengan Instansi pemerintah terkait penanggulangan HIV AIDS serta mencoba untuk mendapatkan bantuan nutrisi dan obat bagi waria yang menjadi Orang Dengan HIV/AIDS (ODHA).

Ada 8 orang waria di Kota Tanjungpinang yang bekerja sebagai aktivis dalam LSM HIV/AIDS. Mereka juga terlibat dalam kegiatan sosialisasi kondom khususnya kepada waria di Tanjungpinang yang menjajakan dirinya sebagai pekerja seks di Pamedan dan Tenis Ban.

2. Donasi untuk Muslim Rohingya

Waria di Tanjungpinang punya kepedulian yang besar dengan para pengungsi muslim Rohingya di Myanmar. Mereka menggalang donasi untuk muslim Rohingya. Ini adalah bentuk toleransi yang mereka ajarkan kepada masyarakat kolektif di Tanjungpinang. Mereka menyadari bagaimana rasanya menjadi pihak minoritas yang disingkirkan dari daerahnya. Diskriminasi, kekerasan dan eksploitasi yang dialami oleh waria di Tanjungpinang sepertinya membuat mereka mampu merasakan kesulitan muslim Rohingya.

\section{Menggelar Peringatan HUT RI}

Para waria bersama masyarakat Tanjungpinang menggelar peringatan HUT RI. Mereka mengikuti perlombaan layaknya masyarakat pada umumnya dan juga memberikan hiburan berupa pertunjukan seni karena beberapa dari mereka mahir menyanyyi dan menari.

\section{Menyesuaikan Penampilan Selama Siang Hari}

Guna membaur dalam masyarakat mayoritas, waria di Tanjungpinang menyesuaikan penampilannya selama siang hari. Mereka berpakaian seperti laki-laki pada umumnya dan berupaya bertingkah laku seperti lelaki. 


\section{KESIMPULAN}

Kendati waria dianggap sebagai kelompok manusia yang menyimpang dari nilai-nilai moral dan agama, negara tetap berkewajiban menyediakan pemenuhan kebutuhan dasar sepanjang pelayanan tersebut tidak bertentangan atau mencederai rasa keimanan atau religiositas masyarakat, seperti pelayanan kesehatan, pendidikan, dan fasilitas publik yang sensitif terhadap 'sense of identity' waria.

\section{REFERENSI}

Afrizal. (2005). Pengantar Metode Pneleitian Kualitatif: Dari Pengertian Sampai Penulisan Laporan. Padang: Andalas University Press

Bastaman ,T.K dkk. (2004). Leksikon Istilah Kesehatan Jiwa dan Psikiatri. Jakarta: Buku Kedokteran EGD.

Budianta, Melani. (2014). Ekspresi untuk Identitas. Jakarta: Suarakita.

Budirahayu, Tuti. (2011). Sosiologi Perilaku Menyimpang. Surabaya: PT Revka Petra Media.

Gagnon, Jhon dan Simon. (2004). Sexual Conduct, $2^{\text {nd }}$, Chicago: Aldine

Hamid, Abdul. (2015). Kaum Luth Masa Kini. Jakarta: Yayasan Islam Bina Umat.

Kymlicka, Will. (2003). Kewarganegaraan Multikultural . Teori Liberal mengenai Hak-Hak Minoritas. JakartaL LP3ES.

Koentjaraningrat. (1994). Metode-Metode Penelitian Masyarakat, Jakarta: PT. Gramedia Pustaka Utama.

Koeswinarno. (2004). Hidup sebagai Waria. Yogyakarta : Pelangi Akasara.

Margaret M Poloma, (2004), Sosiologi Kontemporer, Jakarta: Raja Grafindo Persada.

Masri Singarimbun,.(1995). Metode Penelititan Survei, Jakarta: LP3S.

Miles, Matthew B. Dan A. Michael Huberan. (1992). Analisis Data Kualitatif: Buku Sumber Tentang Met ode-Metode Baru. Jakarta: UI-Press.

Moleong, Lexy. J. (2001), Metode Penelitian Kualitatif. Bandung: PT. Remaja Rosdakarya. 
Nadia,Z. (2005).Waria Laknat atau Kodrat. Yogyakarta: Galang Press

Narbuko, C. dan A. Achmadi, (1997). Metodologi Penelitian Yogyakarta: Gajahmada University Press.

Narwoko J Dwi. (2010). Sosiologi: Teks Pengantar dan Terapan. Jakarta: Kencana Predana Media Group.

Pujileksono dan Puspitosari. (2005). Waria dan tekanan sosial. Malang: Universitas Muhammadyah.

Ritzer, G. (2006). Teori Sosial Postmodern. Yogyakarta: Kreasi Wacana.

Scott, Jhon, (2011). Sosiologi The Key Concepts..Jakarta: PT Raja Grafindo. 